\title{
21. ISOTOPE GEOCHEMISTRY OF LEG 129 BASALTS: IMPLICATIONS FOR THE ORIGIN OF THE WIDESPREAD CRETACEOUS VOLCANIC EVENT IN THE PACIFIC ${ }^{1}$
}

\author{
Paterno R. Castillo, ${ }^{2}$ Peter A. Floyd ${ }^{3}$ and Christian France-Lanord ${ }^{4}$
}

\begin{abstract}
Basaltic rocks recovered from three drill sites in the western Pacific during Ocean Drilling Program Leg 129 have fairly distinct $\mathrm{Sr}, \mathrm{Nd}$, and $\mathrm{Pb}$ isotopic compositions. The Cretaceous alkali olivine dolerites from Site 800 in the northern part of Pigafetta Basin have fairly low ${ }^{87} \mathrm{Sr} /{ }^{86} \mathrm{Sr}_{i}(0.70292-0.70320)$ and ${ }^{143} \mathrm{Nd} /{ }^{144} \mathrm{Nd}_{j}(0.51277-0.51281)$ and high present-day $\mathrm{Pb}$ isotopic ratios $\left({ }^{206} \mathrm{~Pb} /{ }^{204} \mathrm{~Pb}=20.53-21.45 ;{ }^{207} \mathrm{~Pb} /{ }^{204} \mathrm{~Pb}=15.70-15.77 ;{ }^{208} \mathrm{~Pb} /{ }^{204} \mathrm{~Pb}=40.02-40.68\right)$. The Middle Jurassic tholeites from Site 801 in the southern part of the basin have low ${ }^{87} \mathrm{Sr}^{86} \mathrm{Sr}_{\mathrm{i}}(0.70237-0.70248)$, high ${ }^{143} \mathrm{Nd}^{144} \mathrm{Nd}_{\mathrm{i}}(0.51298-0.51322)$, and moderate present-day $\mathrm{Pb}$ isotopic ratios $\left({ }^{206} \mathrm{~Pb} /{ }^{204} \mathrm{~Pb}=18.20-19.12 ;{ }^{207} \mathrm{~Pb} /{ }^{204} \mathrm{~Pb}=15.47-15.60 ;{ }^{208} \mathrm{~Pb} /{ }^{204} \mathrm{~Pb}=37.56-38.18\right)$; isotopic compositions of the alkali olivine basalts overlying the tholeiites fall between those of the tholeiites and Site 800 dolerites. The Cretaceous tholeiites from Site 802 in the East Mariana Basin have high ${ }^{87} \mathrm{Sr}^{86} \mathrm{Sr}_{\mathrm{i}}(0.70360-0.70372)$, fairly low ${ }^{143} \mathrm{Nd}^{144} \mathrm{Nd}_{i}$ $(0.51277-0.51280)$, and fairly low and homogeneous present-day $\mathrm{Pb}$ isotopic ratios $\left({ }^{206} \mathrm{~Pb} /{ }^{204} \mathrm{~Pb}=18.37-18.39 ;{ }^{207} \mathrm{~Pb} /{ }^{204} \mathrm{~Pb}=\right.$ $15.49-15.51 ;{ }^{208} \mathrm{~Pb} /{ }^{204} \mathrm{~Pb}=38.34-38.39$ ). Isotopic compositions of Site 801 tholeiites are indistinguishable from those of modern mid-ocean ridge basalts, consistent with the proposal that these tholeiites are a part of the oldest Pacific crust. The diverse isotopic compositions of the younger basalts appear to be the result of Jurassic Pacific plate migration over the geologically anomalous south-central Pacific region, wherein they acquired their distinct isotopic compositions. The anomalous region was volcanically more active during the Cretaceous than at present.
\end{abstract}

\section{INTRODUCTION}

During Leg 129 of the Ocean Drilling Program (ODP) we drilled three sites $(800,801$, and 802) in the western Pacific (Fig. 1) to sample the Jurassic sedimentary section and underlying basaltic basement in that region (Lancelot, Larson, et al., 1990). The three drill sites bottomed in basaltic rocks, but only Site 801 in the southern Pigafetta Basin reached Jurassic crust. An upper sequence of $\sim 60 \mathrm{~m}$ of alkali olivine basalt flows and a lower sequence of $\sim 60 \mathrm{~m}$ of tholeiite basalt flows and pillow units separated by a hydrothermal Fe-oxyhydroxide deposit were penetrated beneath Jurassic sediments at Site 801 . The alkali basalts have a radiometric age of $157 \mathrm{Ma}$ whereas the tholeiites underneath the hydrothermal deposit have a radiometric age of $\sim 167 \mathrm{Ma}$ (Pringle, this volume). Leg 129 drilling at Site 800 in the northern part of the basin penetrated $\sim 100 \mathrm{~m}$ of intrusive dolerite sills underneath Upper Cretaceous sediments. The dolerites have a radiometric age of $126 \mathrm{Ma}$. At Site 802 in the East Mariana Basin, $\sim 50 \mathrm{~m}$ of tholeiitic basalt pillow lavas were drilled below Cretaceous sediments. The Site 802 tholeiites are $\sim 52 \mathrm{~m}$.y. younger, at $115 \mathrm{Ma}$, than the Jurassic tholeiites at Site 801.

In this paper, we present the $\mathrm{Sr}, \mathrm{Nd}$, and $\mathrm{Pb}$ isotopic compositions of the basaltic rocks recovered from Leg 129 drill sites in the western Pacific. These isotopic data are then combined with information on petrology and possible geologic occurrence of these basalts presented in detail elsewhere in this volume (Floyd and Castillo; Floyd et al.). The main objectives of our study were to determine the intersite as well as intrasite compositional variability of the Leg 129 basaltic rocks and to identify their respective mantle sources. Finally, we propose a crustal evolution model of the western Pacific that bears on the origin of the so-called widespread volcanic "event" that occurred

\footnotetext{
'Larson, R. L., Lancelot, Y., et al., 1992. Proc. ODP. Sci. Results, 129: College Station, TX (Ocean Drilling Program)

${ }^{2}$ Geological Research Division, Scripps Institution of Oceanography, La Jolla, CA 92093-0220, U.S.A.

${ }^{3}$ Department of Geology, University of Keele, Staffordshire, ST5 SBG, United Kingdom.

${ }^{4}$ Centre de Recherches Pétrographiques et Géochemiques, B.P. 20, F-54501 Vandoeuvre Cedex, France.
}

in the Pacific Basin during the Cretaceous (e.g., Larson, Schlanger, et al., 1981; Moberly, Schlanger, et al., 1986).

As a secondary objective, we attempted to determine the crystallization ages of two alkalic dolerites (Samples 129-800A-58R-2, $52-60 \mathrm{~cm}$, and $129-801 \mathrm{C}-1 \mathrm{R}-1,109-114 \mathrm{~cm}$ ) using both the Rb-Sr and $\mathrm{Sm}-\mathrm{Nd}$ isotopic methods of dating. We analyzed the $\mathrm{Sr}$ and $\mathrm{Nd}$ isotopic compositions and $\mathrm{Rb}, \mathrm{Sr}, \mathrm{Sm}$, and $\mathrm{Nd}$ elemental concentrations in coexisting mineral phases from these samples. To test the validity of our results, both of these samples were also dated by Pringle (this volume) using the ${ }^{40} \mathrm{Ar} /{ }^{39} \mathrm{Ar}$ single-crystal dating method.

\section{BACKGROUND AND METHODOLOGY}

In general, basaltic rocks from the three Leg 129 drill sites have distinct petrologic characteristics (Lancelot, Larson, et al., 1990; Floyd et al., this volume; Floyd and Castillo, this volume). The Site 800 samples are all alkali olivine dolerites. These are aphyric in texture and consist chiefly of plagioclase and salite and minor amounts of iron oxides and hydroxides, biotite, apatite, spinel, alkali feldspar, hornblende, and pyrite; they are moderately to highly ( $20 \%-55 \%)$ altered. The dolerites are enriched in incompatible elements such as $\mathrm{Ba}, \mathrm{Sr}, \mathrm{La}$, and Ce relative to mid-ocean ridge basalts (MORB), which is typical of many oceanic island basalts (OIB). The upper sequence alkali olivine basalts at Site 801 have a similar but not identical mineralogy with the Site 800 alkalic dolerites. These alkali basalts are also enriched in incompatible elements, but to a lesser degree in comparison to the dolerites. Specifically, the trace element signature of Site 801 alkalic basalts belongs to the mildly alkalic oceanic island group typified by St. Helena and Réunion (Floyd and Castillo, this volume). Site 801 alkalic basalts are variably $(20 \%-80 \%)$ altered. The lower sequence tholeiitic basalts at Site 801 are composed mainly of plagioclase, augite, olivine (always pseudomorphed by secondary clays), and minor amounts of spinel, titano-magnetite, biotite, and apatite. The Site 801 tholeiites are depleted in incompatible elements, which is typical of modern normal-MORB. These tholeites show the widest range of alteration among the basalts recovered from all sites, from slight $(10 \%)$ to very highly altered $(100 \%)$, with the samples directly beneath the hydrothermal deposit showing the greatest alteration. On the average, however, the alteration of Site 801 tholeiites is moderate and directly comparable to that of younger $(<10 \mathrm{Ma})$ oceanic rocks from other 


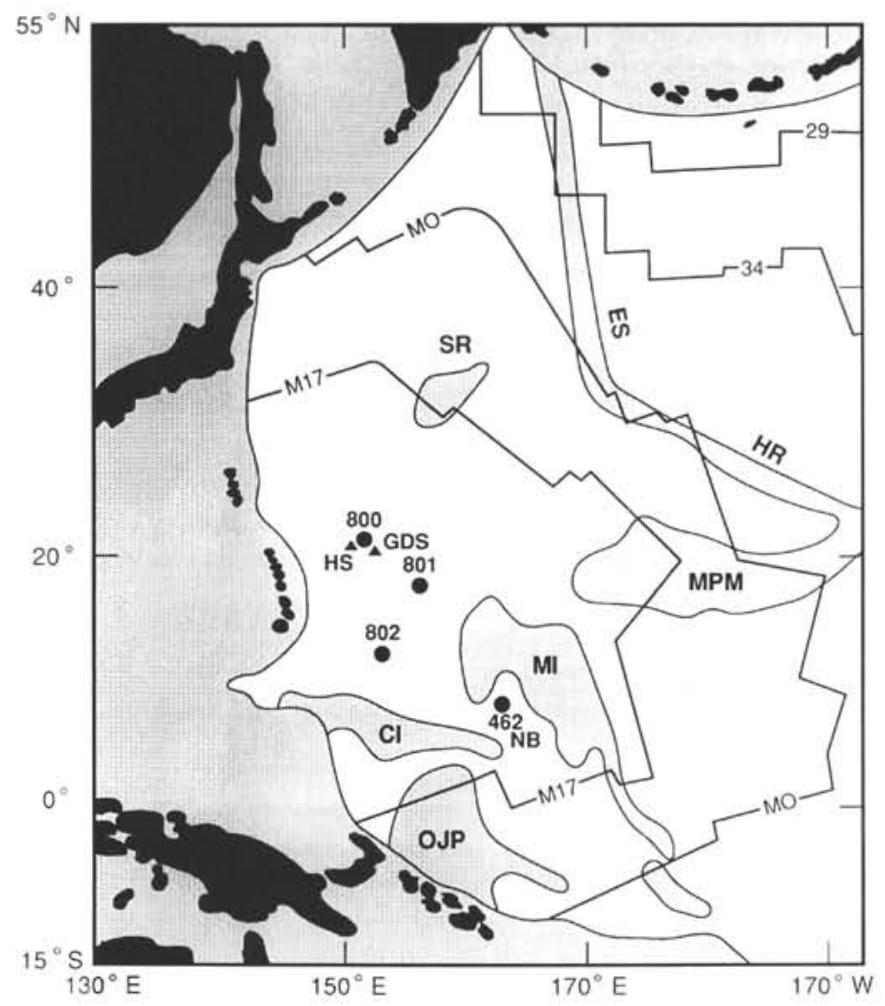

Figure 1. Location of Leg 129 Sites 800, 801, and 802 and DSDP Leg 61 Site 462 (modified after Lancelot, Larson, et al., 1990). Bedrock isochrons based on magnetic anomaly lineations, major oceanic plateaus, western Pacific subduction zones, and Himu and Golden Dragon seamounts are shown for reference. Abbreviations used are as follows: $\mathrm{CI}=$ Caroline Islands, $\mathrm{OJP}=$ Ontong Java Plateau, $\mathrm{MI}=$ Marshall Islands, $\mathrm{NB}=$ Nauru Basin, $\mathrm{MPM}=$ Mid-Pacific Mountains, SR = Shatsky Rise, HR = Hawaiian Ridge, ES = Emperor Seamounts, HS = Himu Seamount, and GDS = Golden Dragon Seamount. Shaded areas represent volcanic edifices with thickened crustal sections, as well as the younger areas beyond the Pacific subduction zones.

regions (Alt et al., this volume). Finally, the Site 802 tholeiitic basalts are slightly to moderately $(10 \%-20 \%)$ altered, with some pillow units still having fresh, glassy selvages. These tholeiites are not as incompatible element - depleted as those from Site 801, but still generally are within the range of modern MORB.

Samples from Site 800 and 801 analyzed for isotopic compositions were carefully selected so as to represent distinct petrologic groups and/or stratigraphic horizons. These were crushed in an all-steel mortar and pestle by hand and then powdered in an alumina ceramic shatterbox. The powders were subjected to a harsh, multistep, $\mathrm{HCl}$-leaching procedure (Mahoney, 1987; Cheng et al., 1987; Castillo et al., 1991) to remove the effects of seawater alteration on these rocks, especially on the $\mathrm{Sr}$ isotopes. Samples analyzed from Site 802 were restricted to the few available glassy selvages of the pillow lavas. Chips of the freshest glasses were carefully hand-picked under a binocular microscope and only lightly leached with mild $\mathrm{HCl}$. The chemical analyses of most of the samples analyzed here are presented by Castillo et al. (this volume).

$\mathrm{All} \mathrm{Pb}$ and most $\mathrm{Sr}$ and $\mathrm{Nd}$ isotopic measurements were done at the Department of Terrestrial Magnetism of the Carnegie Institution of Washington using the procedure described by Castillo et al. (1991; see also Walker et al., 1989). Some of the $\mathrm{Sr}$ and $\mathrm{Nd}$ isotopic determinations were done at the Scripps Institution of Oceanography using the wellestablished procedure there (e.g., Carlson, 1980; Cheng, 1989). Sr and $\mathrm{Nd}$ isotopic measurements of Sample 129-800A-58R-2, 52-60 cm, processed in the two laboratories are similar within errors (Table 1).
$\mathrm{Rb}, \mathrm{Sr}, \mathrm{Sm}$, and Nd elemental determinations of the whole rock samples analyzed for isotopic compositions were done by inductively coupled plasma atomic emission spectrometry (ICP-AES) at the Centre de Recherches Pétrographiques et Géochemiques, using the procedure described by Govindaraju and Mevelle (1987). Rb concentrations of the incompatible element-depleted Site 802 basalts were done by atomic absorption spectrophotometry (AA) at Scripps (C. MacIsac, analyst) because their concentrations are below the detection limit of the ICP-AES method.

Mineral separation of the two coarse-grained samples analyzed for dating purposes was done at the United States Geological Survey (USGS) in Menlo Park and the procedure used is described in detail by Pringle (this volume). In addition to the mineral purification done at the USGS, all the mineral separates were leached in ultraclean $2.5 \mathrm{~N} \mathrm{HCl}$ for $\sim 1 \mathrm{hr}$ under constant agitation in an ultrasonic bath; clinopyroxene separates were further leached in $10 \% \mathrm{HNO}_{3}$ for $\sim 2 \mathrm{~min}$ also under constant agitation. Finally, the separates were rinsed several times with ultraclean water and dried overnight in an oven at $90^{\circ} \mathrm{C}$. All trace element concentration measurements of the rocks and minerals analyzed for dating purposes were done by the isotope dilution method. The accuracy, precision, and isotopic measurement corrections of all the analyses are listed beneath Table 1.

\section{RESULTS AND COMPARISON WITH OTHER OCEANIC BASALTS}

The isotopic compositions of Leg 129 basalts and mineral separates are listed in Table 1 and shown graphically in Figures 2 through 6. A detailed description of the results is presented as follows. First, we discuss the effects of seawater alteration on the isotopic compositions of the samples, then the results of age determination, and finally the isotopic analyses of samples from the three sites. As a whole, basalts from the sites can be separated into four isotopic groups, with Site 801 having two groups. Each group shows a limited to moderate degree of variation but by and large, intragroup variation is small relative to intergroup variation. These isotopic groupings agree well with the petrologic differences observed among the basaltic rocks. In the presentation of the analyses for each site, the isotopic values are generally described relative to the proposed hypothetical end-member mantle components: (1) depleted MORB mantle (DMM), (2) enriched mantle I and II (EM I and EM II), and (3) high $\mathrm{U} / \mathrm{Pb}$ mantle (HIMU) (Figs. 3 through 5; nomenclature is after Zindler and Hart, 1986). The DUPAL isotope anomaly proposed by Hart (1984) is related to the EM components, particularly to EM I.

\section{Alteration Effects}

A major concern in this study is the effects of seawater alteration on the $\mathrm{Sr}, \mathrm{Nd}$, and $\mathrm{Pb}$ isotopic compositions of old (>100 m.y.) basalts that are variably altered by seawater. The best examples are the Site 801 tholeiites directly underneath the hydrothermal deposit. Megascopic, petrographic, physical properties, and chemical evidence (Lancelot, Larson, et al., 1990; Floyd and Castillo, this volume; Alt. et al., this volume; Busch et al., this volume) clearly showed that these are the most altered igneous rocks recovered during Leg 129.

To investigate seawater alteration effects, leached and unleached powders from the interior of two Site 801 tholeiitic cooling units (Samples 129-801C-5R-3, 38-43 cm, and 129-801C-8R-2, 78-80 cm) were analyzed for $\mathrm{Sr}, \mathrm{Nd}$, and $\mathrm{Pb}$ isotopic compositions. The cooling unit that contains Sample $129-801 \mathrm{C}-5 \mathrm{R}-3,38-43 \mathrm{~cm}$, is directly beneath the hydrothermal deposit and is the most altered at Site 801 (Alt et al., this volume; Busch et al., this volume). Leached-unleached pairs of two comparatively less altered alkalic Samples 129-801C-1R-1, 109-114 cm, and $129-800 \mathrm{~A}-61 \mathrm{R}-1,17-24 \mathrm{~cm}$, were also analyzed for their $\mathrm{Sr}$ and $\mathrm{Nd}$ isotopic contents for comparison.

As expected, there is a large difference between the present-day or measured and initial $\mathrm{Sr}$ isotopic values in all pairs (Table 1). Many investigators have shown that the difference is due to the isotopic 
Table 1. Strontium, Nd, and $\mathrm{Pb}$ isotopic compositions of Leg 129 basalts.

\begin{tabular}{|c|c|c|c|c|c|c|c|c|c|c|c|c|c|}
\hline $\begin{array}{l}\text { Core, section, } \\
\text { interval }(\mathrm{cm})\end{array}$ & Type $^{2}$ & $\begin{array}{l}{ }^{87} \mathrm{Sr}{ }^{86} \mathrm{Sr} \\
\text { Measured }\end{array}$ & $\begin{array}{c}{ }^{143} \mathrm{Nd} /{ }^{144} \mathrm{Nd} \\
\text { Measured }\end{array}$ & Error & $\mathbf{R b}$ & $\mathrm{Sr}$ & $\mathrm{Sm}$ & Nd & ${ }^{87} \mathrm{Sr} /{ }^{86} \mathrm{Sn}$ & ${ }^{143} \mathrm{Nd} /{ }^{144} \mathrm{Nd}_{i}$ & $\begin{array}{l}{ }^{206} \mathrm{~Pb} /{ }^{204} \mathrm{~Pb} \\
\text { Measured }\end{array}$ & $\begin{array}{c}{ }^{207} \mathrm{~Pb} /{ }^{204} \mathrm{~Pb} \\
\text { Measured }\end{array}$ & $\begin{array}{l}{ }^{208} \mathrm{~Pb} /{ }^{204} \mathrm{~Pb} \\
\text { Measured }\end{array}$ \\
\hline \multicolumn{14}{|l|}{$129-800 \mathrm{~A}$. } \\
\hline $58 \mathrm{R}-1,12-17$ & L & 0.70323 & 0.512878 & 7 & 25 & 607 & 2.16 & 11.23 & 0.70302 & 0.512782 & 20.977 & 15.718 & 40.089 \\
\hline $58 \mathrm{R}-2,52-60$ & $\mathrm{~L}$ & $-\overline{2}$ & & $\overline{0}$ & $-\overline{2}$ & & - & & 20.988 & 15.722 & 40.258 & & \\
\hline $58 \mathrm{R}-2,52-60$ & $\mathrm{U}$ & 0.70339 & 0.512873 & 23 & 21.31 & 582 & 8.48 & 42.78 & 0.70320 & 0.512774 & - & - & - \\
\hline (Duplicate) & $\vec{U}$ & 0.70336 & 0.512886 & 7 & 21.31 & 582 & 8.48 & 42.78 & 0.70317 & 0.512787 & - & - & - \\
\hline Plagioclase & $\mathrm{U}$ & 0.70281 & 0.512829 & 7 & 9.07 & 1293 & 0.30 & 3.12 & 0.70278 & 0.512781 & - & - & - \\
\hline K-feldspar & $\mathrm{U}$ & 0.70430 & 0.512838 & 23 & 80.08 & 206 & 0.14 & 1.31 & 0.70228 & 0.512786 & - & - & - \\
\hline Clinopyroxene, $5 . g .=2.9$ & $\mathrm{U}$ & 0.70369 & 0.512969 & 25 & 8.54 & 87.3 & 12.22 & 44.58 & 0.70318 & 0.512832 & - & - & - \\
\hline Clinopyroxene, s.g. $=3.2$ & $\mathrm{U}$ & 0.70315 & 0.512969 & 20 & 1.54 & 61.6 & 12.26 & 44.99 & 0.70302 & 0.512833 & - & 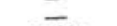 & 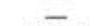 \\
\hline $60 \mathrm{R}-1,69-74$ & $\mathrm{~L}$ & 0.70315 & 0.512909 & 11 & 23 & 536 & 2.39 & 9.56 & 0.70292 & 0.512784 & 20.525 & 15.700 & 40.015 \\
\hline $61 R-1,17-24$ & $\vec{L}$ & 0.70320 & 0.512902 & 8 & 23 & 591 & 2.58 & 13.35 & 0.70300 & 0.512806 & 21.451 & 15.767 & 40.682 \\
\hline \multicolumn{14}{|l|}{ 129-801B- } \\
\hline $43 \mathrm{R}-1,22-27$ & $\mathrm{~L}$ & 0.70347 & 0.512977 & 21 & 29 & 289 & 3.17 & 12.14 & 0.70282 & 0.512814 & 19.223 & 15.556 & 38.413 \\
\hline $44 \mathrm{R}-3,28-33$ & $\mathrm{~L}$ & 0.70322 & 0.513045 & 17 & 27 & 505 & 1.45 & 6.46 & 0.70287 & 0.512905 & 18.951 & 15.545 & 38.167 \\
\hline $4 \mid R-1,26-31$ & $\mathrm{~L}$ & 0.70318 & 0.512996 & 24 & 29 & 445 & 2.09 & 8.82 & 0.70276 & 0.512848 & 19.300 & 15.589 & 38.569 \\
\hline \multicolumn{14}{|l|}{ 129-801C. } \\
\hline IR-1, 109-114 & L & 0.70323 & 0.512980 & 8 & 23 & 369 & 3.32 & 13.65 & 0.70283 & 0.512829 & 19.215 & 15.563 & 38.417 \\
\hline IR-1, 109-114 & $\mathrm{U}$ & 0.70387 & 0.512956 & 19 & 37.48 & 365 & 6.59 & 30.39 & 0.70320 & 0.512821 & - & - & - \\
\hline Clinopyroxene & $\tilde{U}$ & 0.70330 & 0.512990 & 19 & 5.66 & 79.3 & 12.34 & 42.47 & 0.70283 & 0.512809 & - & - & - \\
\hline Clinopyroxene, magnetic & $\mathrm{U}$ & 0.70408 & 0.512972 & 21 & 13.58 & 72.6 & 9.90 & 34.23 & 0.70287 & 0.512792 & - & - & - \\
\hline Plagioclase & $\mathrm{U}$ & 0.70293 & 0.512898 & 26 & 21.85 & 881 & 0.18 & 1.24 & 0.70277 & 0.512806 & - & - & - \\
\hline $5 R-3,38-43$ & $\mathrm{~L}$ & 0.70237 & 0.513443 & 37 & $<1$ & 91 & 1.26 & 3.86 & 0.70237 & 0.513219 & 18.201 & 15.472 & 37.563 \\
\hline $5 R-3,38-43$ & $\vec{U}$ & 0.70302 & 0.513205 & 19 & i & 143 & 2.29 & 6.18 & 0.70295 & 0.512952 & 18.066 & 15.452 & 37.462 \\
\hline $8 \mathrm{R}-2,78-80$ & $\mathrm{~L}$ & & & & & & & & & & 18.499 & 15.541 & 37.781 \\
\hline (Duplicate) & L & 0.70251 & 0.513408 & 23 & $<1$ & 115 & 2.30 & 5.94 & 0.70251 & 0.513143 & 18.496 & 15.481 & 37.671 \\
\hline $8 \mathrm{R}-2,78-80$ & $\mathrm{U}$ & 0.70320 & 0.513209 & 25 & 0.88 & 124 & 4.11 & 10.82 & 0.70315 & 0.512949 & 18.533 & 15.453 & 37.573 \\
\hline $10 \mathrm{R}-6,67-70$ & L & 0.70239 & 0.513266 & 19 & $<1$ & 103 & 1.73 & 4.96 & 0.70239 & 0.513027 & 18.769 & 15.543 & 37.857 \\
\hline IIR-2, 131-136 & $\mathrm{L}$ & 0.70248 & 0.513276 & 20 & $<1$ & 99 & 2.72 & 6.76 & 0.70248 & 0.513001 & 18.326 & 15.492 & 37.676 \\
\hline $12 \mathrm{R}-3,35-37$ & $\mathrm{~L}$ & 0.70248 & 0.513287 & 23 & $<1$ & 117 & 2.15 & 4.72 & 0.70248 & 0.512975 & 19.123 & 15.600 & 38.181 \\
\hline \multicolumn{14}{|l|}{ 129-802A- } \\
\hline $58 \mathrm{R}-2,110-115$ & $\mathrm{U}$ & & 0.512945 & & & & 2.75 & 8.83 & 0.70372 & 0.512804 & & 15.507 & 38.369 \\
\hline $58 \mathrm{R}-2,142-149$ & $\mathrm{U}$ & 0.70373 & 0.512950 & 18 & 1.7 & 94 & 2.91 & 8.86 & 0.70365 & 0.512801 & 18.380 & 15.511 & 38.390 \\
\hline $58 \mathrm{R}-3,0-1$ & U & 0.70374 & 0.512933 & 23 & 1.8 & 90 & 2.60 & 8.24 & 0.70365 & 0.512790 & 18.386 & 15.510 & 38.380 \\
\hline (Duplicate) & $\bar{U}$ & 0.70376 & - & & - & & - & - & & & & & \\
\hline $58 \mathrm{R}-4,65-70$ & $\mathrm{U}$ & 0.70371 & 0.512913 & 15 & 2.3 & 95 & 2.91 & 9.18 & 0.70360 & 0.512769 & 18.367 & 15.500 & 38.346 \\
\hline $59 \mathrm{R}-2,123-127$ & $\vec{U}$ & 0.70371 & 0.512929 & 18 & 2.0 & 92 & 2.44 & 7.89 & 0.70361 & 0.512789 & 18.380 & 15.491 & 38.336 \\
\hline
\end{tabular}

Notes: All concentration data are reported in ppm. - = not determined. Analytical uncertainty on ${ }^{87} \mathrm{Sr} /{ }^{86} \mathrm{Sr}$ measurements is \pm 0.00002 but in-run precisions are a lot better than this; uncertainty on ${ }^{143} \mathrm{Nd} /{ }^{144} \mathrm{Nd}$ is 0.000023 (errors listed are in-run precisions and refer to the last significant digits of the $\mathrm{Nd}$ isotopic compositions; uncertanties on $\mathrm{Pb}$ isotopic compositions are approximately ${ }^{20} \mathrm{~Pb}{ }^{204} \mathrm{~Pb} \pm 0.015$. ${ }^{207} \mathrm{~Pb}{ }^{204} \mathrm{~Pb} \pm 0.019$, and ${ }^{208} \mathrm{~Pb}{ }^{204} \mathrm{~Pb} \pm 0.06$. Sr isotopic ratios were fractionation corrected to ${ }^{86} \mathrm{Sr} /{ }^{88} \mathrm{Sr}=0.1194$ and normalized to ${ }^{87} \mathrm{Sr} /{ }^{86} \mathrm{Sr}=0.71025$ for $\mathrm{NBS}$ 987; Nd isotopic ratios were measured in oxide form and fractionation corrected to ${ }^{146} \mathrm{NdO} /{ }^{144} \mathrm{NdO}=0.72225\left({ }^{146} \mathrm{Nd} /{ }^{144} \mathrm{Nd}=0.7219\right)$ and are reported relative to ${ }^{143} \mathrm{Nd} /{ }^{144} \mathrm{Nd}=0.511860$ for the La Jolla Standard; isotopic compositions of $\mathrm{Pb}$ were corrected for mass fractionation based on average measured values for NBS 981 using the values given in Catanzaro et al. (1968). Initial isotopic compositions (with subscript i) were calculated for an assumed age of 173 m.y. for Site 801 tholeiites, 157 m.y. for Site 801 alkali basalts, 126 m.y. for Site 800 dolerites, and 115 m.y. for Site 802 tholeiites. The Sr isotopic compositions of Site 801 tholeiites were not corrected for age because these are incompatible element-depleted tholeites with very low $\mathrm{Rb} / \mathrm{Sr}(<0.01)$ ratios, and thus corrections are negligible. Rb, $\mathrm{Sr}$, Sm, and $\mathrm{Nd}$ concentrations of whole-rock samples were determined by ICP-AES and AA except those of Samples 129-800A-58R-2, 52-60 cm, and 129-80 IC-1R-1, 109-114 cm, and the mineral separates which were analyzed by the isotope dilution method. The uncertainties of trace element abundance determinations by ICP-AES and AA are generally better than $5 \%$, whereas those by isotope dilution are better than $1 \%$. ${ }^{a} \mathrm{U}=$ unleached; $\mathrm{L}=$ leached; $\mathrm{s}, \mathrm{g}$. = specific gravity.

exchange between rock and seawater, which contains $\sim 8 \mathrm{ppm} \mathrm{Sr}$, during alteration (e.g., McCulloch et al., 1980; Cheng et al., 1987). Seawater contains only a small amount of $\mathrm{Nd}$ at $2.6 \times 10^{-6} \mathrm{ppm}$ (e.g., Piepgras and Wasserburg, 1980,1982) and our results show that the difference between the measured and initial $\mathrm{Nd}$ isotopic compositions of unleached and leached powders is significantly smaller than that for $\mathrm{Sr}$. In fact, there is virtually no difference between leached and unleached initial Nd isotopic values for the less altered alkalic samples. However, measured leached values are generally higher than unleached values - consistent with our previous results (Castillo et al., 1991). We have suggested that this is generally the case for the $\mathrm{HCl}$-leaching procedure because this type of leaching proxies as a mineral separation technique as it differentially dissolves $\mathrm{Sm}$ - and Nd-bearing phases. Under the microscope, leached powders are composed mainly of fine plagioclase and clinopyroxene grains, whereas unleached powders are composed of mixtures of different mineral/rock grains and clays (see also Mahoney, 1987). Thus, the systematic difference between leached and unleached measured $\mathrm{Nd}$ isotopic values in the alkalic samples is most probably an artifact of the leaching procedure. However, this notion is probably not true for the highly altered tholeiites, as the difference in their leached and unleached values, particularly in their initial isotopic compositions, are well outside the analytical uncertainty. In accordance with megascopic, petrographic, chemical, and physical properties evidence, we believe that the $\mathrm{Nd}$ isotopic compositions of the most altered tholeiites, similar to $\mathrm{Sr}$, have been affected by seawater alteration.

The measured $\mathrm{Pb}$ isotopic compositions of the leached and unleached aliquots of Samples 129-801C-5R-3, 38-43 cm, and 129$801 \mathrm{C}-8 \mathrm{R}-2,78-80 \mathrm{~cm}$, are different (Table 1). The $\mathrm{Pb}$ isotopic ratios of extremely (up to $90 \%$ ) altered Site 801 tholeiites (P. R. Castillo, unpubl. data, 1992) are also different from those of the less altered part of the same cooling unit, suggesting that the $\mathrm{Pb}$ isotopic compositions of Leg 129 basalts may also have been affected by seawater alteration (cf. Mahoney and Spencer, 1991). Based on these results, we measured the $\mathrm{Pb}$ isotopic ratios of leached whole rock powders only to (1) correct the isotopic compositions for possible seawater alteration effects and (2) ensure that $\mathrm{Sr}, \mathrm{Nd}$, and $\mathrm{Pb}$ isotopic values for each sample are from the same aliquot. The following discussion on the isotopic characteristics of Leg 129 samples will refer to measured $\mathrm{Pb}$ and initial $\mathrm{Sr}$ and $\mathrm{Nd}$ isotopic ratios determined from leached powders. Exceptions are Sample-129-800A-58R-2, 52-60 cm, because almost all of its mineral phases were analyzed for age dating purposes, and the carefully hand-picked, cleaned Site 802 tholeiitic glasses.

\section{Crystallization Ages}

Isotopic data for mineral separates from Samples 129-801C-1R-1, $109-114 \mathrm{~cm}$, and 129-800A-58R-2, 52-60 cm, form two linear arrays in both the $\mathrm{Rb}-\mathrm{Sr}$ and $\mathrm{Sm}-\mathrm{Nd}$ isochron diagrams (Fig. 2). However, the two "isochrons" in the Sm-Nd system are defined by data points that are not well correlated (both $R^{2}=\sim 0.92$ ); these give imprecise "dates" of 136 $\pm 40 \mathrm{Ma}$ for Sample 129-801C-IR-1, 109- $114 \mathrm{~cm}$, and $167 \pm 59 \mathrm{Ma}$ for Sample 129-800A-58R-2,52-60 cm. The case is even worse in the $\mathrm{Rb}-\mathrm{Sr}$ system (both $R^{2}<0.88$ ); the dates given by the isochrons are $171 \pm 76$ Ma for Sample 129-801C-1R-1, 109-114 cm, and 77 \pm 50 Ma for Sample $129-800 \mathrm{~A}-58 \mathrm{R}-2,52-60 \mathrm{~cm}$. Moreover, the mineral phases and whole rock from each sample do not have the same initial $\mathrm{Sr}$ and $\mathrm{Nd}$ isotopic values (Table 1) and these data indicate that there seems to be isotopic disequilibrium in the samples analyzed. For comparison, crystallization age determined by the ${ }^{40} \mathrm{Ar} /{ }^{39} \mathrm{Ar}$ single-crystal method on the plagioclases and a small amount of biotite from Sample 129-801C-1R-1, $109-119 \mathrm{~cm}$, is $156.9 \pm 0.4 \mathrm{Ma}$, whereas on the K-feldspar from Sample 

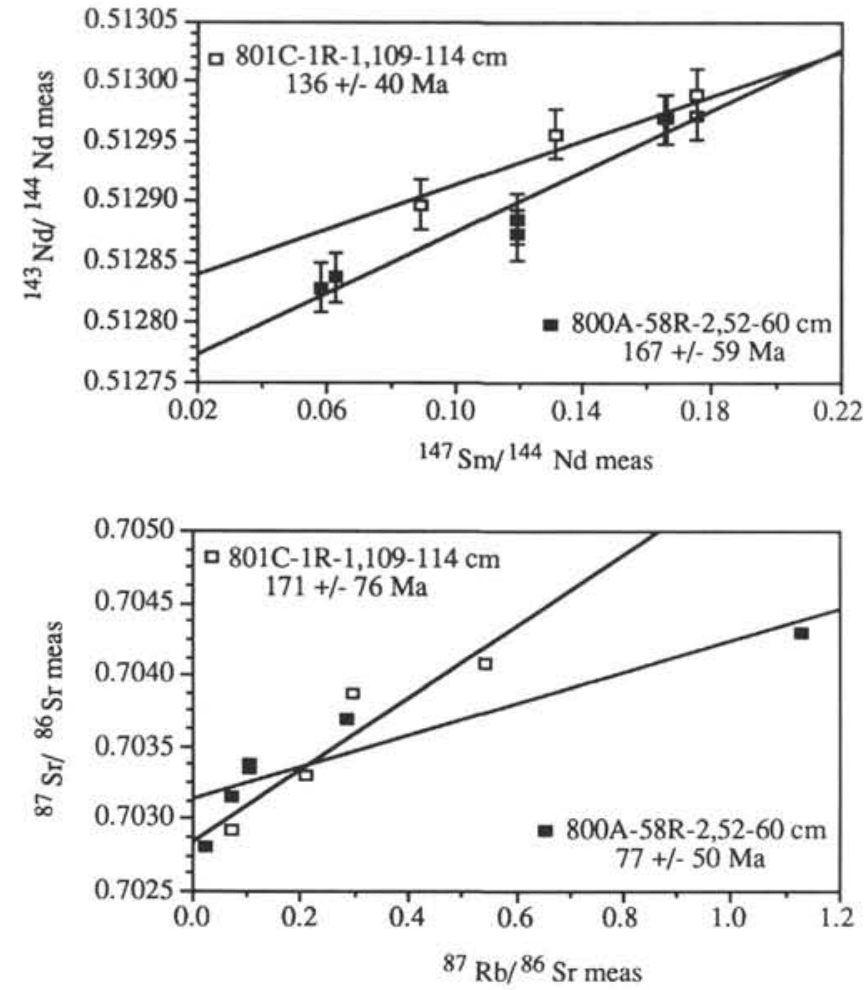

Figure 2. $\mathrm{Sm}-\mathrm{Nd}$ and $\mathrm{Rb}-\mathrm{Sr}$ isochron diagrams for whole rocks and coexisting minerals in Samples 129-801C-1R-1, 109-114 cm, and 129-800A-58R-2, $52-60 \mathrm{~cm}$. Each line was fitted to all the points for each sample except for the $\mathrm{Rb}-\mathrm{Sr}$ line for Sample 129-80IC-1R-1, 109-114 cm, in which the whole-rock value was not included to get a better fit. Given their large errors, the Sm-Nd and $\mathrm{Rb}-\mathrm{Sr}$ dates of the two samples agree with the ${ }^{40} \mathrm{Ar} /{ }^{39} \mathrm{Ar}$ ages, but certainly our results show that the crystallization ages of Leg 129 samples can not be determined accurately by the $\mathrm{Rb}-\mathrm{Sr}$ and $\mathrm{Sm}-\mathrm{Nd}$ dating methods.

129-800A-58R-2, 52-60 cm, is $126.1 \pm 0.9 \mathrm{Ma}$ (Pringle, this volume). These ${ }^{40} \mathrm{Ar} /{ }^{39} \mathrm{Ar}$ crystallization ages are consistent with the biostratigraphically determined ages of the sediments overlying these igneous samples (Matsuoka, this volume; Erba and Covington, this volume).

Results of previous studies have shown that the $\mathrm{Rb}-\mathrm{Sr}$ isotope systematics is sensitive to seawater alteration (e.g., McCulloch et al., 1980; Faure, 1986) and, thus, it is not surprising that we failed to get reliable $\mathrm{Rb}-\mathrm{Sr}$ dates. An attempt to date the sill and flow complex in the nearby Nauru Basin using different size fractions of igneous samples by the $\mathrm{Rb}-\mathrm{Sr}$ method was also not successful (Notsu et al., 1986). The Rb-Sr dating method, however, has been employed quite successfully in dating celadonite veins in oceanic crust (e.g., Staudigel et al., 1981; Hart and Staudigel, 1986). For example, the celadonite veins in the same Nauru sills and flows studied by Notsu et al. (1986) yield an age of 105.1 \pm $2.8 \mathrm{Ma}$ (Hart and Staudigel, 1986), which is well within the age of formation of the complex determined by the ${ }^{40} \mathrm{Ar} /{ }^{39} \mathrm{Ar}$ method and the biostratigraphy of the interbedded sediments (Moberly, Schlanger, et al., 1986). It is important to note that the ages of celadonite veins determined by this method, though, are commonly younger than the crystallization age of the host oceanic crust because they are sensitive to the history of hydrothermal activity in the host oceanic crust.

An analogue of our Sm-Nd age determination study is that by McCulloch et al. (1980), who determined the crystallization age of the Samail ophiolite complex in Oman. The complex is an exceptionally well preserved and exposed cross section of oceanic crust and, and unlike many Leg 129 samples, some of its rocks have not experienced intense

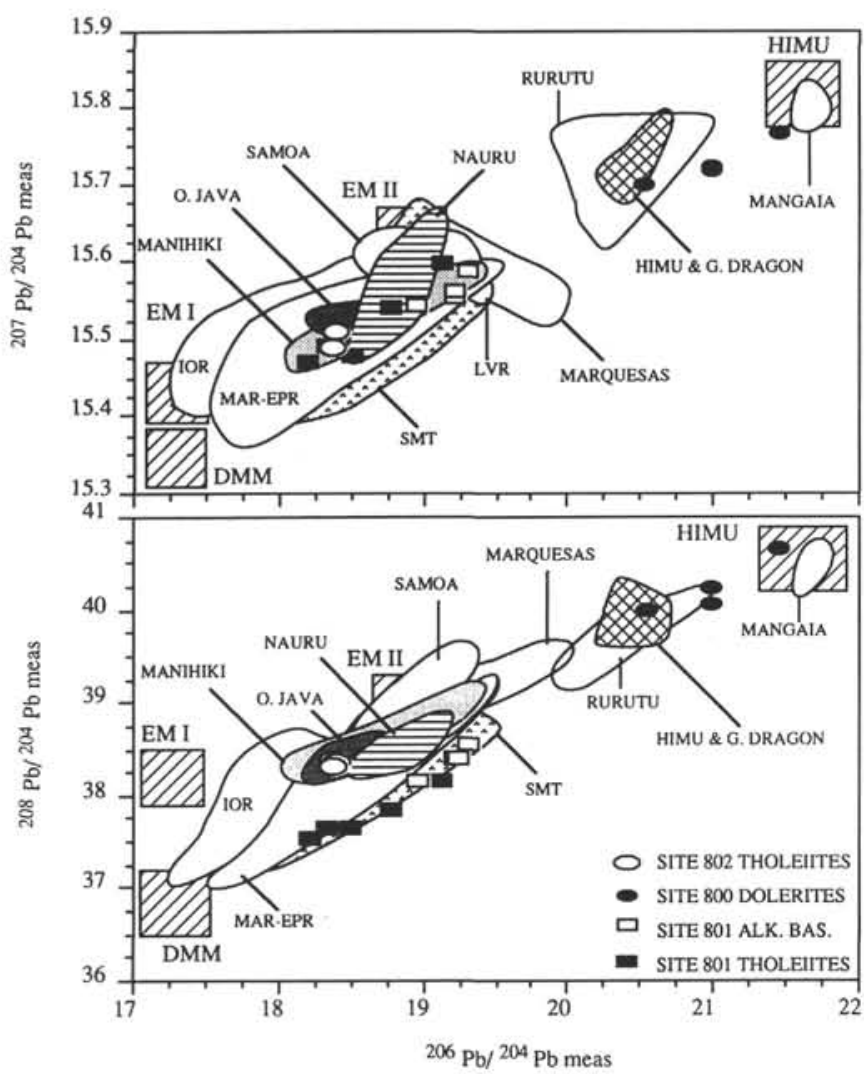

Figure 3. Measured ${ }^{206} \mathrm{~Pb} /{ }^{204} \mathrm{~Pb}$ against measured ${ }^{207} \mathrm{~Pb} /{ }^{204} \mathrm{~Pb}$ and against measured ${ }^{208} \mathrm{~Pb} /{ }^{204} \mathrm{~Pb}$ correlation diagrams for Leg 129 basalts. Analytical uncertainties are given in Table 1. The proposed mantle end-member components and fields for selected oceanic basalts (after Staudigel et al., 1991; Castillo et al., 1991) are shown for reference. Abbreviations used are as follows: $\mathrm{EPR}=$ East Pacific Rise; $\mathrm{MAR}=$ Mid-Atlantic Ridge; $\mathrm{IOR}=$ Indian Ocean ridges; SMT = near-ridge seamounts LVR = Louisville Ridge.

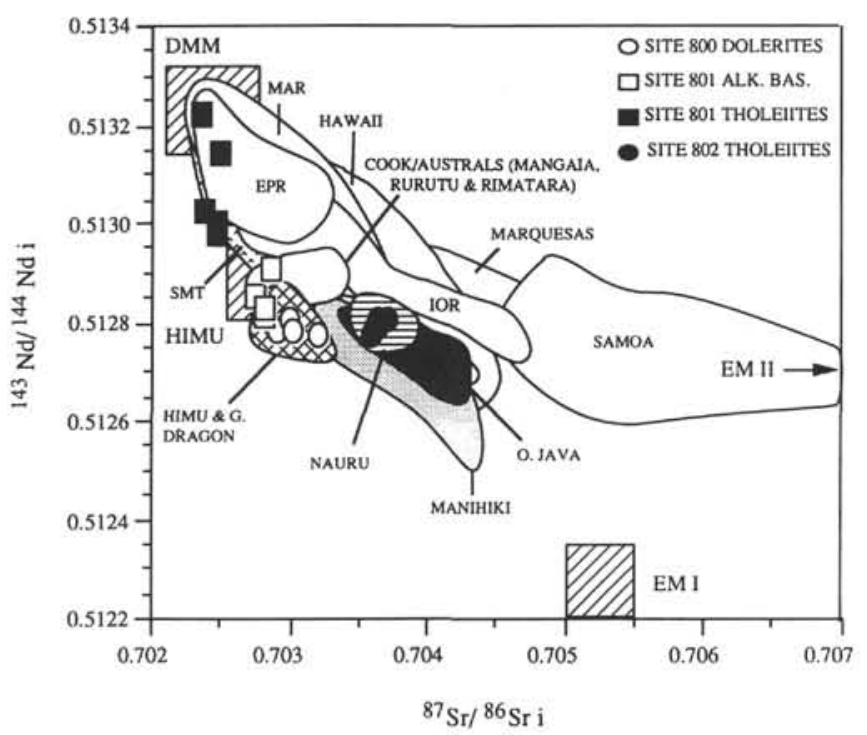

Figure 4. Initial ${ }^{87} \mathrm{Sr} /{ }^{86} \mathrm{Sr}$ against initial ${ }^{143} \mathrm{Nd} /{ }^{144} \mathrm{Nd}$ correlation diagram for Leg 129 basalts. Sources of data are as in Figure 3. Discussion is in the text. 


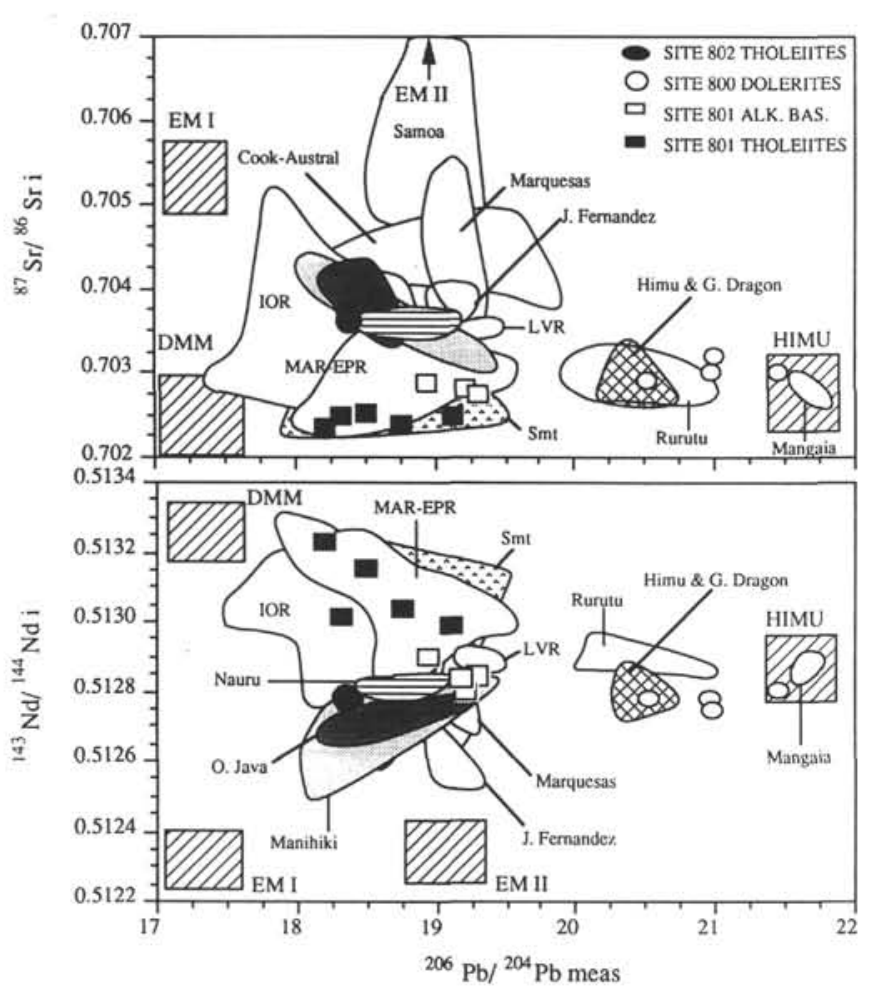

Figure 5. Measured ${ }^{206} \mathrm{~Pb} /{ }^{204} \mathrm{~Pb}$ against initial ${ }^{87} \mathrm{Sr} /{ }^{86} \mathrm{Sr}$ and against initial ${ }^{143} \mathrm{Nd} /{ }^{144} \mathrm{Nd}$ correlation diagrams for Leg 129 basalts. Sources of data are as in Figure 3. Discussion is in the text.

interaction with seawater. Coexisting clinopyroxene and plagioclase in four oceanic gabbros from Samail differ greatly in their ${ }^{147} \mathrm{Sm} /{ }^{144} \mathrm{Nd}$ ratios $(0.129-0.377)$. These mineral fractions define two excellent internal isochrons (both $R^{2}=\sim 1.0$ ) that give crystallization ages of $130 \pm 12 \mathrm{Ma}$ and $100 \pm 20 \mathrm{Ma}$, which were interpreted as the time of formation of two portions of the complex. In the present study, the range of ${ }^{147} \mathrm{Sm} /{ }^{144} \mathrm{Nd}(0.058-0.176)$ is more than a factor of 2 less than that of the Samail samples and, coupled with seawater alteration, gives larger age uncertainties.

\section{Site 800 Dolerites}

These dolerites have the highest measured $\mathrm{Pb}$ isotopic ratios among the samples analyzed here (Fig. 3) or, for that matter, ever reported for any oceanic igneous rocks drilled by ODP or the earlier Deep Sea Drilling Project (DSDP). Although the Site 800 dolerites have high $\mathrm{Pb}$ isotopic values, these have relatively low $\mathrm{Sr}$ and intermediate $\mathrm{Nd}$ isotopic compositions (Fig. 4). Site 800 dolerites plot below the so-called mantle-array or the linear trend defined by the majority of oceanic lavas in $\mathrm{Nd}$ and $\mathrm{Sr}$ isotopic space; they belong to the "LoNd" array with Tubuaii Island and Walvis Ridge as end points in $\mathrm{Sr}-\mathrm{Nd}-\mathrm{Pb}$ isotopic space (Gerlach et al., 1986). More accurately, the isotopic compositions of the dolerites almost overlap with those of Mangaia, which has even more extreme $\mathrm{Pb}$ isotopic compositions than Tubuaii. Magmas from Tubuaii and Mangaia, as well as St. Helena in the Atlantic, were proposed to be the closest representatives of the hypothetical HIMU end-member component in the mantle. Mantle component with HIMU characteristics has a high ${ }^{238} \mathrm{U} /{ }^{204} \mathrm{~Pb}$ ratio $(\mu)$ that is needed to explain the high ${ }^{206} \mathrm{~Pb} /{ }^{204} \mathrm{~Pb}$ (e.g., White, 1985; Zindler and Hart, 1986; Hart, 1988).

Major and trace element data indicate an OIB mantle source for Site 800 dolerites (Floyd et al., this volume), but it is difficult to relate

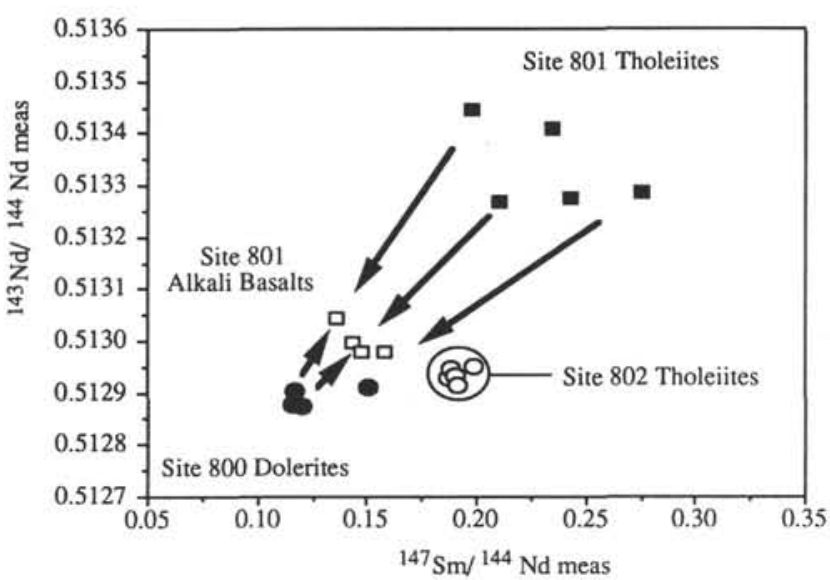

Figure 6. Measured ${ }^{147} \mathrm{Sm} /{ }^{144} \mathrm{Nd}$ against measured ${ }^{143} \mathrm{Nd} /{ }^{144} \mathrm{Nd}$ for Leg 129 basalts showing that it is possible to produce the mantle source of Site 801 alkali basalts by mixing (arrows) the sources of Site 801 tholeiites and Site 800 dolerites. Site 802 tholeiites do not lie in the mixing trend.

these dolerites to a particular type of island or island group using chemical data alone. The distinct isotopic signature of the dolerites is similar to those of basalts from St. Helena in the Atlantic or from islands in the Cook-Australs in the southern Pacific, such as Rurutu, Mangaia, and Tubuaii (Figs. 3 through 5). The Site 800 dolerites and OIB from these islands were derived from mantle sources with a HIMU isotopic signature. Recently, Staudigel et al. (1991; see also Smith et al., 1989) have shown that some Cretaceous volcanoes from the Magellan, Marshall, and Wake seamount groups also have HIMU isotopic characteristics. Of particular importance in this study is the isotopic similarity between Site 800 dolerites and Himu and Golden Dragon Seamount alkalic rocks because it places important constraints on the mode of emplacement of the dolerites. Himu Seamount is only $\sim 80 \mathrm{~km}$ to the southwest of Site 800 and is only $6 \mathrm{~m}$.y. younger than the dolerites (Smith et al., 1989). Although Golden Dragon is located $\sim 160 \mathrm{~km}$ southeast of the site and is $25 \mathrm{~m}$.y. younger than the dolerites, its origin is identical to that of Himu Seamount (Smith et al., 1989; Staudigel et al., 1991). The origin of the seamounts and its relationship to the emplacement of Site 800 dolerites will be discussed in more detail in the following section.

\section{Site 801 Alkalic and Tholeiitic Basalts}

The Jurassic tholeiites in the southern Pigafetta Basin have low ${ }^{87} \mathrm{Sr} /{ }^{86} \mathrm{Sr}$ and moderately high, though variable, ${ }^{143} \mathrm{Nd} /{ }^{144} \mathrm{Nd}$ compared to other oceanic basalts (Fig. 4). A couple of Site 801 tholeiites have high $\mathrm{Nd}$ and low $\mathrm{Sr}$ isotopic compositions that are near the high ${ }^{143} \mathrm{Nd} /{ }^{144} \mathrm{Nd}$ and low ${ }^{87} \mathrm{Sr} /{ }^{86} \mathrm{Sr}$ end of the mantle array. This indicates that they came from a mantle source that has a long time-integrated depletion in $\mathrm{Rb}$ with respect to $\mathrm{Sr}$ and $\mathrm{Nd}$ with respect to $\mathrm{Sm}$. Such a mantle source is similar to the hypothetical DMM end-member component, which is widely believed to constitute the bulk of the uppermost suboceanic mantle; it is also regarded as the main component in the mantle source of MORB (White, 1985; Zindler and Hart, 1986). Site 801 tholeiites have a moderately wide range of $\mathrm{Pb}$ isotopic compositions, but as a whole, they resemble the $\mathrm{Pb}$ isotopic signature of Pacific and Atlantic MORB more than any other group of oceanic lavas (Fig. 3).

The Site 801 tholeiites are the oldest oceanic basalts recovered in situ in the western Pacific and their radiometric age ( 167 Ma; Pringle, this volume) is very close to the predicted Jurassic age of the seafloor based on magnetic lineations (Larson, 1976; Handschumacher et al., 1988). Most important, all their lithologic and geo- 
chemical features indicate a normal spreading-axis origin (Floyd and Castillo, this volume). These data clearly indicate that the tholeiites are the Jurassic equivalent of modern normal-MORB. The fact that the isotopic data for these tholeiites also are indistinguishable from modern normal-MORB from the Pacific and Atlantic oceans (Fig. 3 through 5) strongly support the other geologic arguments.

The Site 801 alkali basalts have higher ${ }^{87} \mathrm{Sr} /{ }^{86} \mathrm{Sr}$ and lower ${ }^{143} \mathrm{Nd} /{ }^{144} \mathrm{Nd}$ isotopic ratios than the tholeiites (Fig. 4). The $\mathrm{Pb}$ isotopic compositions of the alkali basalts also are more restricted and more radiogenic, as well as apparently trend to lower ${ }^{207} \mathrm{~Pb} /{ }^{204} \mathrm{~Pb}$ for given ${ }^{206} \mathrm{~Pb} /{ }^{204} \mathrm{~Pb}$ than the tholeiites (Fig. 3). However, as a whole, their $\mathrm{Pb}$ isotopic compositions still overlap with those of the tholeiites. Site 801 alkali basalts also plot within the elongated MORB field in the $\mathrm{Sr}$ against $\mathrm{Pb}$ isotope diagram (Fig. 5).

Major and trace element data suggest an OIB mantle source for Site 801 upper sequence alkali basalts (Floyd and Castillo, this volume). Indeed, the presence of a hydrothermal deposit and a temporal gap $(\sim 10 \mathrm{~m} . \mathrm{y}$.) between the lower sequence tholeites and these alkali basalts indicate that the latter were emplaced off-axis. However, the $\mathrm{Sr}, \mathrm{Nd}$, and $\mathrm{Pb}$ isotopic ratios of Site 801 alkali basalts do not consistently overlap with any particular OIB (Figs. 3 through 5). Moreover, it is important to emphasize that the $\mathrm{Pb}$ and $\mathrm{Sr}$ isotopic compositions of these alkali basalts are still within the range of MORB. Furthermore, bathymetric and seismic data suggest a fairly flat topography of the seafloor at Site 801 (Lancelot, Larson, et al., 1990), and Leg 129 drilling showed that the upper sequence alkali basalts is only $\sim 60 \mathrm{~m}$ thick. These data are inconsistent with the presence of a prominent volcanic chain or plateau in the vicinity of Site 801 and place an important constraint on the size of the volcanic conduit of the upper sequence alkali basalts.

In detail, the $\mathrm{Sr}, \mathrm{Nd}$, and $\mathrm{Pb}$ isotopic compositions of Site 801 alkali basalts fall in between those of the Site 801 tholeiites and Site 800 alkali basalts (Figs. 3 through 5 ). This may suggest that the source of Site 801 alkali basalts is a product of mixing of sources of the Site 800 alkali basalts, with HIMU isotopic characteristics, and the Site 801 tholeiites, with a DMM geochemical signature. This mixing relationship is supported by the plot of $\mathrm{Nd}$ isotopes against ${ }^{147} \mathrm{Sm} /{ }^{144} \mathrm{Nd}$ (Fig. 6) which shows that Site 801 alkali basalts fall exactly between the Site 800 alkali basalts and Site 801 tholeiites.

The isotopic compositions of Site 801 alkali basalts overlap with those of isolated seamounts formed near mid-ocean ridges (Zindler et al., 1984; Graham et al., 1988; Castillo and Batiza, 1989; Hegner and Tatsumoto, 1989). These seamounts are ubiquitous on the ocean floor (Batiza, 1982; Fornari et al., 1987; Smith and Jordan, 1988) although their formation and evolution apparently are strongly influenced by the tectonic and magma supply processes at mid-ocean ridges if the seamounts were formed on <10-m.y.-old lithosphere (Fornari et al., 1987). For example, the bulk of seamounts is made up of tholeiitic basalts that for the most part are petrologically indistinguishable from MORB. But there are also seamounts that erupt alkalic lavas (e.g., Smt. 6 and N-5 of Batiza and Vanko, 1984). If the upper sequence alkali basalts were part of a small, isolated seamount on the Jurassic ocean floor, then this may explain their MORB/OIB-like isotopic signature despite their strong OIB geochemical character (Floyd and Castillo, this volume). The affiliation of the upper sequence alkali basalts to a small seamount rather than to a large volcano connected to a major seamount chain also satisfies the topographic constraints imposed by the bathymetric and seismic data.

\section{Site 802 Tholeiitic Basalts}

The basaltic glasses have only moderate $\mathrm{Nd}$ but the highest $\mathrm{Sr}$ isotopic composition among the samples analyzed (Fig. 4). These glasses plot close to the center of the bulk of oceanic lava $\mathrm{Sr}$ and $\mathrm{Nd}$ isotopic data. Site 802 tholeiites also have the most limited range of $\mathrm{Pb}$ isotopic compositions among the samples analyzed (Fig. 3).
Another distinctive feature of these tholeites is their high ${ }^{208} \mathrm{~Pb} /{ }^{204} \mathrm{~Pb}$ for given a ${ }^{206} \mathrm{~Pb} /{ }^{204} \mathrm{~Pb}$, which, together with the high ${ }^{87} \mathrm{Sr} /{ }^{86} \mathrm{Sr}$ values, forms some of the characteristic features of oceanic lavas that have the DUPAL isotopic signature (Hart, 1984). These oceanic basalts must have come from mantle sources that have a long-term $(>1 \mathrm{Ga})$ history of incompatible element enrichment and, thus, must have been isolated in the mantle for a long period of time (Hart, 1984).

The Site 802 tholeiites have petrographic and bulk chemical characteristics typical of tholeiitic basalts from mid-ocean ridges (Floyd et al., this volume). Specifically, these are hypersthene-normative basalts that are depleted in incompatible trace elements. However, East Mariana basalts are neither as incompatible element depleted as normal-MORB nor as incompatible element enriched as those erupted near hotspots or plume-MORB. For example, some of their trace element ratios that indicate the degree of incompatible element depletion such as $\mathrm{La} / \mathrm{Sm}_{(\mathrm{N})}(0.98$ [ave.] \pm 0.24 [std. dev.]), $\mathrm{La} / \mathrm{Yb}(1.57 \pm 0.58)$, and $\mathrm{Zr} / \mathrm{Nb}(15.4 \pm 1.8)$ are in between the values of normal- and plume-MORB. Site 802 tholeiites are directly comparable to those of transitional MORB from certain sections of the ocean ridge such as the Reykjanes Ridge and the Costa Rica Rift. In these regards, Site 802 tholeiites are geochemically similar to the tholeiitic basalts recovered at DSDP Site 462 in the Nauru Basin (Larson, Schlanger, et al., 1981; Moberly, Schlanger, et al., 1986; Floyd, 1989; Castillo et al., 1986, 1991). The similarity is even more striking because of their identical $\mathrm{Sr}$ and Nd isotopic compositions (Fig. 4). Site 802 and Site $462 \mathrm{~Pb}$ isotopic compositions strictly speaking do not overlap, but the field for the entire $\sim 640 \mathrm{~m}$ of the Nauru complex (Castillo et al., 1991) trends toward the limited field for the glassy $\sim 19 \mathrm{~m}$ top of the pillow lavas drilled in the East Mariana Basin (Fig. 3). In addition, new ${ }^{40} \mathrm{Ar} /{ }^{39} \mathrm{Ar}$ age data for the Site 462 tholeiites (M. Pringle, unpubl. data, 1992) suggest that the East Mariana Basin and Nauru Basin tholeiites were emplaced contemporaneously. Altogether, these data bear on the origin of both igneous bodies and this will be discussed in more detail in the following section.

Similar to the Nauru tholeiites, the isotopic compositions of Site 802 tholeiites overlap both with some OIB and MORB (Figs. 3 through 5). The Site 802 tholeiites overlap with MORB from the South Atlantic and Indian Ocean, which have some attributes of the DUPAL isotopic signature (Dupre and Allègre, 1983; Hart, 1984; Castillo, 1988; Mahoney et al., 1989). These tholeiites do not overlap with modern MORB from the Pacific. The isotopic compositions of Site 462 and 802 tholeiites also overlap with those of OIB from oceanic islands such as the Marquesas, San Felix, Juan Fernandez, and Hawaii in the Pacific. More importantly, the isotopic compositions of Site 802 tholeiites are very similar to the Ontong Java and Manihiki plateaus (Mahoney, 1987; Mahoney and Spencer, 1991), which apparently were formed contemporaneously with the eruption of Site 462 and 802 tholeiites (e.g., Pringle, this volume; Tarduno et al., 1991). These plateau basalts have an EM I and/or DUPAL isotopic signature (Mahoney, 1987; Mahoney and Spencer, 1991).

\section{DISCUSSION}

The preceding presentation shows that the origin of Site 800 alkalic and Site 801 tholeiitic magmas can be traced back, respectively, close to the proposed hypothetical HIMU and DMM end-member components in the mantle. The mantle source of Site 801 alkalic magma is most probably a mixture of these two components. The Site 802 magma resulted from mixing DMM and EM I, most probably in the source, due to their fairly limited isotopic and geochemical variations. Very similar isotopic compositions are known to have persisted for a long period of time (>10 m.y.) and over a large area in the nearby Site 462 tholeiites, and hence, most probably is an inherent feature of the mantle source (Castillo et al., 1991). The important problem that will be addressed here is the relationship between the distinct isotopic signatures of Leg 129 basaltic magmas and the tectonic evolution of the western Pacific. Based on the available 
information, we propose a model to explain the origin of the widespread volcanic event that occurred in the western Pacific during the Cretaceous (e.g., Larson, Schlanger, et al., 1981; Moberly, Schlanger, et al., 1986).

The recovery of the lower sequence tholeiites at Site 801 in the southern part of Pigafetta Basin verifies the presence of the oldest Pacific crust in that region as predicted by plate reconstruction models based on seafloor magnetic lineations (e.g., Larson, 1976; Handschumacher et al., 1988). All available data indicate that the tholeiites were erupted along a mid-ocean ridge system. This system most probably is a Middle Jurassic boundary of the oldest Pacific plate though it is impossible to trace whether this is the Pacific-Farallon, Pacific-Phoenix, or Pacific-Izanagi plate boundary because of a lack of correlatable magnetic lineation patterns near the site (e.g., Handschumacher et al., 1988). An important point is that the bulk compositions of the old samples and modern MORB erupted along the eastern boundaries of the Pacific plate (e.g., White et al., 1987; Ito et al., 1987; Macdougall and Lugmair, 1986) are similar and must have come from the incompatible element-depleted upper mantle. In other words, the isotopic data imply that the ridge that formed Site 801 tholeiites was away from hotspots and/or isotopically anomalous regions in the mantle (e.g., Allègre et al., 1984; Hanan et al., 1986; Castillo, 1988). The presence of alkali olivine basalts at Site 801 on top of the hydrothermal deposit, therefore, is interesting because of their fairly homogeneous, but mixed OIB and MORB isotopic signature. One possible explanation is that Site 801 was actually above a transition zone between a "normal" ocean ridge and an anomalous mantle such that the off-axis volcanism that produced the alkali basalts tapped a mixed mantle source. For example, isolated seamount lavas from such a zone tend to magnify the isotope differences that are present in the mantle but are subdued in MORB by magmatic plumbing processes along the ridge (e.g., Castillo and Batiza, 1989). Alternatively, the Jurassic tholeiitic basement moved toward an isotopically diverse and volcanically active off-ridge region at $\sim 157 \mathrm{Ma}$. This would explain not only the isotopic composition of the alkali basalts but also the possible cause of volcanism that formed the basalts and drove the hydrothermal system beneath these basalts. In either case, there is a need for a mantle source (i.e., one that is dominated by a HIMU component) to explain the formation of the upper alkali basalt sequence. Interestingly, Site 800 dolerites in the northern part of Pigafetta Basin originated directly from such a mantle source $\sim 30 \mathrm{~m} . \mathrm{y}$. later.

The isotopic compositions of Site 800 dolerites consistently overlap with those of the Cretaceous Himu and Golden Dragon seamounts (Figs. 3 through 5). Site 800 is also geographically close to these Cretaceous seamounts (Fig. 1) and, thus, it is reasonable to assume that the formation of Site 800 dolerites and seamount magmas are closely related. Smith et al. (1989; see also, Staudigel et al., 1991) showed that the Cretaceous Himu and Golden Dragon seamounts can be "backtracked" to the Rurutu hotspot in French Polynesia (south central Pacific) at zero age using a plate reconstruction model based on a hotspot frame of reference (Henderson, 1985; Duncan and Clague, 1985). They also emphasized the presence of HIMU and EM II (EM I is only minor) components as well as a thermal anomaly in the upper mantle beneath French Polynesia since $\sim 120 \mathrm{Ma}$. They called this isotopically and thermally "anomalous" region SOPTA, which is approximately the same area that was termed the south Pacific "superswell" by McNutt and Fisher (1987). If this is the case, then the Site 800 dolerites most probably were emplaced when their underlying Jurassic lithosphere moved close to or directly over the anomalous region at $\sim 126 \mathrm{Ma}$.

The emplacement of Site 802 and Site 462 MORB-like tholeiites most probably is also connected to the presence of the anomalous region in south central Pacific. Earlier, we have proposed that the Site 462 tholeiites in the Nauru Basin were erupted along an ocean ridge system that propagated into or was formed in the preexisting Jurassic basement when this basement drifted near the intensely volcanically active south central Pacific region during the Cretaceous (Castillo et al., 1986, 1991).
The intense volcanism in this region, in turn, may be related to the large-scale mantle convection (e.g., Hart, 1984, 1988; Castillo, 1988). We believe that the Site 802 tholeiites were produced by a similar process and in fact, their morphologic features as pillow lavas that presently lie beneath $\sim 6000 \mathrm{~m}$ of water (Lancelot, Larson, et al., 1990) make them better suited for the proposed ocean ridge origin. It is important to note that the main arguments against Site 462 tholeiites being MORB, besides the fact that they are younger than the predicted age of the crust in the Nauru Basin, are that the upper part of the complex consists of intrusive sills and that the whole complex is anomalously shallow for a Jurassic-age crust.

An alternative and widely believed origin of the Site 462 tholeiites is that these are intraplate volcanic lavas that were erupted off-axis, $\sim 15-45$ m.y. after the formation of the underlying Jurassic crust (Larson, Schlanger, et al., 1981; Moberly, Schlanger, et al., 1986; Floyd, 1989; Renkin and Sclater, 1988). Of course, the Site 802 tholeiites could have been emplaced in a similar fashion. A third plausible explanation for the origin of the Site 802 tholeiites is that these are products of fracturing and extensional melting in the lithosphere proximal to the anomalous region (e.g., Castillo and Pringle, 1991). However, although the Site 802 tholeiites could have been produced by this process because it may only be a thin cap of the Jurassic basement (cf. Clague et al., 1990), this may not be true for the thick ( $>640 \mathrm{~m}$ ) Site 462 tholeiites. In any event, the volcanism that produced these Cretaceous MORB-like tholeiites most probably were connected to the anomalous region since both Sites 802 and 462 were in the southern hemisphere in the Pacific during the Cretaceous (Wallick and Steiner, this volume).

The similarity of the isotopic compositions of the Sites 802 and 462 tholeiites and those of the Ontong Java Plateau also bears directly on the origin of these tholeiites. The plateau forms the western boundary of the Nauru Basin and the southern boundary of the East Mariana Basin prior to the formation of the Caroline Islands from the Miocene to Recent (Fig. 1). Recent models for the formation of the Ontong Java Plateau call for a mantle plume somewhere between $\sim 34^{\circ} \mathrm{S}$ to as far south as the present location of the Louisville hotspot at $\sim 51^{\circ} \mathrm{S}, 139^{\circ} \mathrm{W}$ (e.g., Tarduno et al., 1991; Mahoney and Spencer, 1991; Richards et al., 1991). Although these locations lie to the south of French Polynesia, the plume that produced the Ontong Java Plateau $\left(\sim 50 \times 10^{6} \mathrm{~km}^{3}\right)$ must have been robust, especially if the plateau was emplaced in a short period of time (a few million years; Tarduno et al., 1991). Moreover, the strong EM I signature of the voluminous plateau lavas (Mahoney and Spencer, 1991) and the somewhat less pronounced EM I characteristics of the Site 462 igneous complex (Castillo et al., 1991) and Site 802 tholeiites (Figs. 3 through 5) are volumetrically minor in modern French Polynesia basalts (e.g., Staudigel et al., 1991; Mahoney and Spencer, 1991). These data are consistent with the idea that a mantle source dominated by an EM I component was active in the South Pacific during the Cretaceous but is no longer there at present. Altogether, the data suggest that the anomalous region may have been larger during the Cretaceous than at present (Larson, 1991) and that a ridge system could have been easily associated with the Ontong Java hotspot (Mahoney and Spencer, 1991), one which formed the Site 462 and 802 tholeiites.

\section{CONCLUSIONS}

Leg 129 drilled the northern (Site 800) and southern (Site 801) parts of the Pigafetta Basin and the central (Site 802) East Mariana Basin to sample the oldest oceanic crust in the western Pacific. Basaltic rocks were recovered from the bottom of the three sites. Results of our isotopic investigations of these basaltic rocks are as follows:

1. An attempt to determine the crystallization ages of the basaltic rocks by the $\mathrm{Rb} / \mathrm{Sr}$ and $\mathrm{Sm} / \mathrm{Nd}$ isotope methods of dating was not successful. This is mainly due to seawater alteration and small range of parent/daughter elemental ratios, but may also be due to the 
presence of xenocrystic phases in the samples (Pringle and Castillo, work in progress).

2. Isotopic compositions of the Middle Jurassic tholeiites from Site 801 resemble those of modern normal-MORB. These tholeiites are the oldest oceanic crust recovered in situ in the Pacific and must have been produced along an accreting boundary of the oldest Pacific plate.

3. Isotopic compositions of the alkali olivine basalts overlying the tholeiites at Site 801 fall between those of the tholeiites and Site 800 dolerites. The volcanism that produced these basalts must have tapped a mantle source produced by mixing the hypothetical DMM and HIMU end-member components.

4. The Cretaceous alkalic lavas from Site 800 in the northern part of the Pigafetta Basin and those of the nearby Himu and Golden Dragon seamounts must have come from the same mantle source with HIMU isotopic characteristics.

5. The Cretaceous MORB-like tholeiites from Site 802 in the East Mariana Basin and from Site 462 in the adjacent Nauru Basin are isotopically very similar. These tholeiites were emplaced contemporaneously and their emplacement may have been initiated by the intense plume activity that formed the Ontong Java Plateau.

6. A simple model of the crustal evolution of the western Pacific can be constructed based on the results of our isotopic investigations combined with other recently available data. The oldest Pacific crust was formed during the Jurassic along a section of a normal ocean ridge similar to those elsewhere in the eastern Pacific today. The Jurassic crust moved toward the south central Pacific region, which may be geologically anomalous since about $157 \mathrm{Ma}$ to the present, and the Site 801 alkali olivine basalts were emplaced. Volcanism became more intense in the south central Pacific region during the Cretaceous due to the possible occurrence of numerous, voluminous hotspot magmatism (e.g., Larson, 1991; Pringle, 1991) and/or impingement of a large mantle plume on the oceanic lithosphere that formed the Ontong-Java Plateau (Richards et al., 1991). The basaltic rocks at Sites 800,802 and 462 were emplaced during this period. Since then, the Pacific crust has moved to the northwest, and volcanism in south central Pacific has been reduced to the current level of intensity.

\section{ACKNOWLEDGMENTS}

We thank M. Hamilton, K. Klewin, R. Carlson, S. Shirey, and C. MacIsac for their help during the analyses and M. Pringle for his help in the mineral separation and age data reduction. Critical reviews by J. Mahoney, W. White, and J. Tarduno were sincerely appreciated and resulted in substantial improvement of the manuscript. This manuscript was supported by a grant from JOI-USSP (TAMU P/O 20511) to P. Castillo.

\section{REFERENCES}

Allègre, C. J., Hamelin, B., and Dupre, B., 1984. Statistical analysis of isotopic ratios of MORB: the mantle blob cluster model and the convective regime of the mantle. Earth Planet. Sci. Lett., 71:71-84.

Batiza, R., 1982. Abundances, distribution and sizes of volcanoes in the Pacific Ocean and implications for the origin of non-hotspot volcanoes. Earth Planet. Sci. Lett., 60:195-206.

Batiza, R., and Vanko, D., 1984. Petrology of young Pacific seamounts. J. Geophys. Res., 89:11235-11260.

Carlson, R. W., 1980. Crust-mantle differentiation on the earth and moon: evidence from isotopic studies for contrasting mechanisms and duration [Ph.D. dissert.]. Univ. of California, San Diego.

Castillo, P. R., 1988. The Dupal anomaly as a trace of the upwelling lower mantle. Nature, 336:667-670.

Castillo, P. R., and Batiza, R., 1989. Sr, Nd and Pb isotope constraints on near-ridge seamount production beneath the South Atlantic. Nature, 342:262-265.

Castillo, P. R., Batiza, R., and Stem, R., 1986. Petrology and geochemistry of Nauru Basin igneous complex: large-volume, off-ridge eruptions of MORB- like basalt during the Cretaceous. In Moberly, R., Schlanger, S. O., et al., Init. Repts. DSDP, 89: Washington (U.S. Govt. Printing Office), 555-576.

Castillo, P. R., Carlson, R. W., and Batiza, R., 1991. Origin of Nauru Basin igneous complex: $\mathrm{Sr}, \mathrm{Nd}$, and $\mathrm{Pb}$ isotope and REE constraints. Earth Planet. Sci. Lett., 103:200-213.

Castillo, P. R., and Pringle, M. S., 1991. Cretaceous volcanism in the western Pacific sampled at Sites 800 and 802, ODP Leg 129. Eos, 72:300. (Abstract)

Catanzaro, E. L., Murphy, T. J., and Shields, W. R., 1968. Absolute isotopic abundance ratios of common, equal-atom, and radiogenic lead isotopic standards. J. Res. Natl. Bur. Stand., 72A.

Cheng, Q., Park, K.-H., Macdougal, J. D., Zindler, A., Lugmair, G. W., Hawkins, J., Lonsdale, P., and Staudigel, H., 1987. Isotopic evidence for a hot spot origin of the Louisville seamount chain. In Keating, B., Fryer, P., Batiza, R., and Boehlert, G. (Eds.), Seamounts, Islands and Atolls. Am. Geophys. Union Monogr., 43:283-296.

Cheng, Q. C., 1989. Geochemical studies of hot spot volcanism in the southern Pacific and its implications for mantle structure and dynamics [Ph. D. dissert.]. Univ. of California, San Diego.

Clague, D., Holcomb, R., Sinton, J., Detrick, R., and Torresa, M., 1990. Pliocene and Pleistocene alkalic flood basalts on the seafloor north of the Hawaiian islands. Earth Planet. Sci. Lett., 98:175-191.

Duncan, R. A., and Clague, D. A., 1985. Pacific plate motions recorded by linear volcanic chains. In Nairn, A.E.M., Stehli, F. G., and Uyeda, S. (Eds.), The Ocean Basins and Margins (Vol. 7A): The Pacific Ocean: New York (Plenum), 89-121.

Dupre, B., and Allègre, C. J., 1983. Pb-Sr isotope variations in Indian Ocean basalts and mixing phenomena. Nature, 303:142-146.

Faure, G., 1986. Principles of Isotope Geology: New York (Wiley).

Floyd, P. A., 1989. Geochemical features of intraplate oceanic plateau basalts. In Saunders, A. D., and Norry, M. J. (Eds.), Magmatism in the Ocean Basins. Geol. Soc. Spec. Publ. London, 42:215-230.

Fornari, D. J., Batiza, R., and Luckman, M. A., 1987. Seamount abundances and distribution near the East Pacific Rise $0^{\circ}-24^{\circ} \mathrm{N}$ based on seabeam data. In Keating, B., Fryer, P., Batiza, R., and Boehlert, G. (Eds.), Seamounts, Islands and Atolls. Am. Geophys. Union Monogr., 43:13-21.

Gerlach, D. C., Hart, S. R., Morales, V.W.J., and Palacios, C., 1986. Mantle heterogeneity beneath the Nazca Plate: San Felix and Juan Fernandez islands. Nature, 322:165-169.

Govindaraju, K., and Mevelle, G., 1987. Fully automated dissolution and separation methods for inductively coupled plasma atomic emission spectrometry rock analysis. Application to the determination of rare earth elements. J. Anal. Atom. Spectr., 2:615-672.

Graham, D., Zindler, A., Kurz, M., Jenkins, W., Batiza, R., and Staudigel, H., 1988. $\mathrm{He}, \mathrm{Pb}, \mathrm{Sr}$, and $\mathrm{Nd}$ isotope constraints on magma genesis and mantle heterogeneity beneath young Pacific seamounts. Contrib. Mineral. Petrol., 99:446-463.

Hanan, B. B., Kingsley, R. H., and Schilling, J.-G., 1986. Pb isotope evidence in the south Atlantic for migrating ridge-hotspot interactions. Nature, 322:137-144.

Handschumacher, D. W., Sager, W. W., Hilde, T. W., and Bracey, D. R., 1988. Pre-Cretaceous tectonic evolution of the Pacific plate and extension of the geomagnetic polarity reversal time scale with implications for the origin of the Jurassic "Quiet Zone." Tectonophysics, 155:365-380.

Hart, S. R., 1984. A large-scale isotope anomaly in the southern hemisphere mantle. Nature, 309:753-757.

, 1988. Heterogeneous mantle domains: signatures, genesis and mixing chronologies. Earth Planet. Sci. Lett., 134:235-253.

Hart, S. R., and Staudigel, H., 1986. Ocean crust vein mineral deposition: $\mathrm{Rb} / \mathrm{Sr}$ ages, U-Th-Pb geochemistry, and duration of circulation at DSDP Sites 261,462 and 516. Geochim. Cosmochim. Acta, 50:2751-2761.

Hegner, E., and Tatsumoto, M., 1989. Pb, Sr, and Nd isotopes in seamount basalts form the Juan de Fuca Ridge and Kodiak-Bowie Seamount Chain, Northeast Pacific. J. Geophys. Res., 94:17839-17846.

Henderson, L. J., 1985. Pacific plate hot spot tracks [Ph.D. dissert.]. Northwestern Univ., Evanston.

Ito, E., White, W., and Gopel, C., 1987. The O, Sr, Nd and Pb isotope geochemistry of MORB. Chem. Geol., 62:157-176.

Klein, E. M., Langmuir, C. H., Zindler, A., Staudigel, H., and Hamelin, B., 1988. Isotope evidence of a mantle convection boundary at the AustralianAntarctic Discordance. Nature, 333:623-629.

Lancelot, Y., Larson, R., et al. 1990. Proc. ODP, Init. Repts., 129: College Station, TX (Ocean Drilling Program). 
Larson, R. L., 1976. Late Jurassic and Early Cretaceous evolution of the western Pacific Ocean: J. Geomagn. Geoelectr., 28:219-236.

-, 1991. The latest pulse of the Earth: evidence for a mid-Cretaceous super plume. Geology, 19:547-550.

Larson, R. L., Schlanger, S. O., et al., 1981. Init. Repts. DSDP, 61: Washington (U.S. Govt. Printing Office).

Macdougall, J. D., and Lugmair, G., 1986. Sr and Nd isotopes in basalts from the East Pacific Rise: significance for mantle heterogeneity. Earth Planet. Sci. Lett., 77:273-284.

Mahoney, J. J., 1987. An isotopic survey of Pacific oceanic plateaus: implications for their nature and origin. In Keating, B., Fryer, P., Batiza, R., and Boehlert, G. (Eds.), Seamounts, Islands and Atolls. Am. Geophys. Union Monogr., 43:283-296.

Mahoney, J. J., Natland, J. H., White, W. M., Poreda, R., Bloomer, S. M., Fisher, R. L., and Baxter, A. N., 1989. Isotopic and geochemical provinces of the western Indian Ocean spreading centers. J. Geophys. Res., $94: 4033-4052$.

Mahoney, J. J., and Spencer, K. J., 1991. Isotopic evidence for the origin of the Manihiki and Ontong Java oceanic plateaus. Earth Planet. Sci. Lett., 103:305-311.

McCulloch, M. T., Gregory, R. T., Wasserburg, G. J., and Taylor, H. P., 1980. A neodymium, strontium, and oxygen isotopic study of the Cretaceous Samail ophiolite and implications for the petrogenesis-seawater hydrothermal alteration of oceanic crust. Earth Planet. Sci. Lett., 46:201-211.

Mcnutt, M. K., and Fischer, K. M., 1987. The south Pacific superswell. In Keating, B., Fryer, P., Batiza, R., and Boehlert, G. (Eds.), Seamounts, Islands and Atolls. Am. Geophys. Union Monogr., 43:25-34.

Moberly, R., Schlanger, S. O., et al., 1986. Init. Repts. DSDP, 89: Washington (U.S. Govt. Printing Office).

Notsu, K., Onuma, N., and Fujii, N., 1986. Rb-Sr isotope systematics and $\mathrm{Sr} / \mathrm{Ca}$ and $\mathrm{Ba} / \mathrm{Ca}$ ratios of Nauru Basin basalts, DSDP Leg 61. In Moberly, R., Schlanger, S. O., et al., Init. Repts. DSDP, 89: Washington (U.S. Govt. Printing Office), 523-527.

Piepgras, D. J., and Wasserburg, G. J., 1980. Nedymium isotopic variations in seawater. Earth Planet. Sci. Lett., 50:128-138.

1982. Isotopic composition of neodymium in waters from the Drake Passage. Science, 217:207-214.

Pringle, M. A., 1991. Rolling thunder of the Early Cretaceous: plateau basalts, EMI from the lower mantle and the origin of the Dupal anomaly. Eos, 72:300.
Renkin, M., and Sclater, J. G., 1988. Depth and age in the North Pacific. J. Geophys. Res., 93:2919-2935.

Richards, M. A., Jones, D. L., Duncan, R. A., and DePaolo, D. J., 1991. A mantle plume initiation model for the formation of Wrangelia and other oceanic flood basalt plateaus. Science, 254:263-266.

Smith, D. K., and Jordan, T. H., 1988. Seamount statistics in the Pacific Ocean. J. Geophys. Res., 93:2899-2918.

Smith, W.H.F., Staudigel, H., Watts, A. B., and Pringle, M. S., 1989. The Magellan Seamounts: Early Cretaceous record of the south Pacific isotopic and thermal anomaly. J. Geophys. Res., 94:10501-10523.

Staudigel, H., Hart, S. R., and Richardson, S. H., 1981. Alteration of the oceanic crust: processes and timing. Earth Planet. Sci. Lett., 52:311-327.

Staudigel, H., Park, K.-H., Pringle, M., Rubenstone, J. L., Smith, W.H.F., and Zindler, A., 1991. The longevity of the south Pacific isotopic and thermal anomaly. Earth Planet. Sci. Lett., 102:24-44.

Tarduno, J. A., Sliter, W. V., Kroenke, L., Leckie, M., Mayer, H., Mahoney, J. J., Musgrave, R., Storey, M., and Winterer, E. L., 1991. Rapid formation of Ontong Java Plateau by Aptian mantle plume volcanism. Science, 254:399-403.

Walker, R. J., Carlson, R. W., Shirey, S. W., and Boyd, F. R., 1989. Os, Sr, Nd and $\mathrm{Pb}$ isotope systematics of southern African peridotite xenoliths: implications for the chemical evolution of subcontinental mantle. Geochim. Cosmochim. Acta, 53:1583-1595.

White, W., Hofmann, A., and Puchelt, H., 1987. Isotope geochemistry of Pacific Mid-ocean ridge basalt. J. Geophys. Res., 92:4881-4893.

White, W. M., 1985. Sources of oceanic basalts: radiogenic isotopic evidence. Geology, 13:115-118.

Zindler, A., and Hart, S., 1986. Chemical geodynamics. Annu. Rev. Earth Planet. Sci., 14:493-571.

Zindler, A., Staudigel, H., and Batiza, R., 1984. Isotope and trace element geochemistry of young Pacific seamounts: implications for the scale of upper mantle heterogeneity. Earth Planet. Sci. Lett., 70:175-195.

Date of initial receipt: 3 June 1991

Date of acceptance: 25 November 1991

Ms 129B-131 